DE DE GRUYTER

OPEN

\title{
EFFECT OF VARIOUS LEVELS OF DIETARY PROTEIN IN TRANSITION PERIOD ON COLOSTRUM QUALITY AND SERUM IMMUNOGLOBULIN CONCENTRATION IN HOLSTEIN COWS AND THEIR NEWBORN CALVES*
}

\author{
Elahe Toghyani ${ }^{\star}$, Ali Moharrery \\ Department of Animal Science, Agricultural College, Shahrekord University, \\ Post code: 34141-88186, Shahrekord, Iran \\ •Corresponding author: elahe.toghyani@gmail.com
}

\begin{abstract}
This experiment was conducted to investigate the effect of 2 levels of crude protein (CP) content in the diet during transition period on lactation performance, colostrum quality and serum immunoglobulin concentration of dairy cows and their newborn calves. Thirty dry Holstein cows $(607 \pm 75 \mathrm{~kg})$ were blocked according to their parity and expected calving date, and then randomly assigned to one of $\mathbf{2}$ treatments of $\mathbf{1 5}$ cows in completely randomized block design. Dietary treatments were: 1) moderate $C P$ level in transition diet (prepartum: 11.9\%; postpartum: 14\%); and 2) higher $\mathrm{CP}$ level in transition diet (prepartum: 14.2\%; postpartum: 16.8\%). Furthermore, milk samples were collected on two days (15 and 30) postpartum for milk composition analysis. At the same time, milk yield also was recorded. After parturition calves were fed mother's colostrum. Colostrum samples were collected during the first milking postpartum. Blood samples of cows were taken on days 21 and 2 before projected calving date and on days 15 and 30 after parturition. Blood samples of calves were collected at $72 \mathrm{~h}$ postcalving and then on days 7, 14, 21 and 28 after birth. Applied treatment had no effect on average milk production on days 15 and 30 postpartum. Colostrum density was lower in cows fed higher $\mathrm{CP}$ level in transition diet than in those fed the diet with moderate $\mathrm{CP}$ content $(\mathrm{P}<\mathbf{0 . 0 5})$. However, the chemical composition of colostrum was not affected by CP level. Serum IgG concentration was higher for calves from higher CP group than for those from moderate $\mathrm{CP}$ level group at 21 days of age $(\mathrm{P}<0.05)$. In conclusion, the increased protein level during periparturient period tended to improve immune status of calves.
\end{abstract}

Key words: Holstein cows, calf, dietary protein, colostral IgG, immunity

The transition period is accompanied by reduced feed intake and metabolic changes at parturition imposing high stress on dairy cows (Guo et al., 2007). Therefore, nutrition of cows during this period is of great importance and influences the

\footnotetext{
*Work funded by Shahrekord University.
} 
health and lactation performance in postpartum period. Although studies conducted so far have failed to show any effect of increasing CP level in prepartum period on lactation performance of dairy cows (Van Saun et al., 1993; Huyler et al., 1999), Santos et al. (2001) suggested that feeding higher CP diet before calving enhanced milk production during the first 120 days in milk. Additionally, using protein supplement in dry period has been shown to increase the milk production and milk protein yield of Holstein-Friesian cows (Moorby et al., 1996). Regarding these trials, increasing $\mathrm{CP}$ level during transition period needs more investigation. On the other hand, a key management objective is to ensure that the calf survives and remains healthy. Due to the syndesmochorial type of placenta, the maternal immunoglobulins do not reach calves' bloodstream. Therefore calves remain immune deficient at birth and their own immune system also takes time to become mature and protective (Banks, 1982). The initial mammary secretion of glands at or near parturition is termed colostrum (Barrington et al., 2001). Colostrum is loaded with immune, growth and tissue repair factors (Uruakpa et al., 2002). Ingestion of colostrum which contains non-nutritive substances, like immunoglobulins, helps neonatal calves to build up their immunity passively (Blum, 2006).

Colostral concentration of immunoglobulins in dairy cattle varies depending on breed, age, season and nutrition (Zarcula et al., 2010). Similarly, small variations of colostral IgG were shown due to dietary CP level in the diet (Stockdale and Smith, 2004). Further, the work of Jaster (2005) indicated that calves receiving colostrum with high $\mathrm{IgG} 1$ content had more serum $\mathrm{IgG}_{1}$ than those fed lower quality colostrum. On the other hand, the impact of maternal $\mathrm{CP}$ nutrition during late pregnancy has been studied by some researchers who believed that colostral IgG concentration was not affected by CP concentration in prepartum diet (Godden, 2008; Santos et al., 2001). However, Hough et al. (1990) and also Burton and Erskine (2003) illustrated that, although colostral IgG concentration was not influenced by prepartum CP intake, their absorption in digestive tract was significantly reduced in calves born from mothers fed restricted amount of CP during their late pregnancy. It is also important to evaluate the correlation between serum immunoglobulin concentration of cows fed different protein levels in transition period and subsequent transferred immunoglobulin into their colostrum.

Therefore, regarding the need to conduct a more in-depth study on feeding different levels of CP in diets during periparturient period and its subsequent effect on colostrum quality and IgG absorption, this experiment was carried out to evaluate the effect of two levels of CP in transition diet on lactation performance, colostrum quality and serum immunoglobulin concentrations of dams and their newborn calves.

\section{Material and methods}

\section{Cows, diets, and treatments}

Thirty dry Holstein cows (10 primiparous and 20 multiparous; $607 \pm 75 \mathrm{~kg}$ ) were blocked according to their parity (mean parity $=2.5$ ) and expected calving date, and 
then randomly assigned to one of 2 treatments of 15 cows each ( 5 primiparous and 10 multiparous) in completely randomized block design. After parturition calves were fed their dam's colostrum. The trial was initiated 21 days prior to the expected calving date and continued until 30 days postcalving. All cows had free access to water throughout the trial. Cows were fed twice daily prior to calving and 3 times daily postcalving with a close-up diet with 2 different protein levels. Treatments were: 1) moderate CP level in the transition diet (prepartum: $11.9 \%$; postpartum: $14 \%$ ); and 2) higher $\mathrm{CP}$ level in transition diet (prepartum: 14.2\%; postpartum: $16.8 \%$ ). The dietary treatments were balanced to meet or exceed NRC (2001) recommendations (Table 1). During the experimental period, cows from each group were kept in separate loose housing and were group fed. One day before the anticipated calving date, cows were moved to the calving box. After parturition, calves were separated from their dams and reared individually in calf cages located next to maternity house. The newborn calves were weighed at birth and then fed maternal colostrum in amount equal to $10 \%$ of body weight within 6 hours after birth. For the 3 subsequent days calves were offered milk. Afterwards, calves were moved to a calf unit and kept in calf hutches. During that period they had free access to water and pelleted starter diet $(\mathrm{CP}=21.9$ and $\mathrm{ME}=2.89 \mathrm{Mcal} / \mathrm{kg})$. Fresh milk was fed twice per day (6:00 and 14:00 h). During early days of life they were fed $2 \mathrm{~L}$ milk per feeding, increasing to up to 3 L per feeding until the end of the experiment. The general information on calves' gender and their distribution between treatments is shown in Table 2.

Table 1. Ingredient and nutrient composition of diets

\begin{tabular}{l|c|c|c|c}
\hline \multirow{2}{*}{\multicolumn{1}{c}{ Composition }} & \multicolumn{4}{c}{ Diet* } \\
\cline { 2 - 5 } & \multicolumn{2}{c}{ Prepartum } & \multicolumn{2}{c}{ Postpartum } \\
\cline { 2 - 5 } \multicolumn{1}{c}{1} & Moderate CP & High CP & Moderate CP & High CP \\
\hline Alfalfa hay, long & 2 & 3 & 4 & 5 \\
Corn silage & 17.97 & 17.20 & 15.76 & 15.20 \\
Barley grain & 54.65 & 52.30 & 37.82 & 36.50 \\
Corn grain & 9.43 & 9.0 & 10.4 & 10.0 \\
Wheat straw & 2.02 & 1.90 & 3.78 & 3.65 \\
Beet pulp & 2.25 & 2.18 & 0.95 & 0.90 \\
Whole cottonseed & - & - & 11.98 & 11.5 \\
Soybean meal & 2.58 & 2.50 & 5.67 & 5.45 \\
Rapeseed meal & 2.17 & 4.25 & 6.30 & 7.90 \\
Cottonseed meal & 1.12 & 1.05 & 1.70 & 1.65 \\
Sunflower meal & - & - & 0.63 & 0.65 \\
Wheat bran & 1.57 & 3.65 & - & 1.85 \\
Fat supplement & - & - & 0.82 & 0.75 \\
Fish meal & - & - & 0.50 & 0.50 \\
Minerals and vitamins Mix ${ }^{1}$ & 0.63 & 0.62 & 0.95 & 0.90 \\
Anionic supplement & 0.74 & 0.70 & 0.44 & 0.40 \\
Sodium bicarbonate & 3.0 & 2.90 & - & - \\
Sodium chloride & - & - & 0.50 & 0.50 \\
Choline chloride & - & - & 0.20 & 0.20 \\
\hline & 0.22 & 0.20 & 0.19 & 0.20 \\
\hline
\end{tabular}


Table 1 - contd.

\begin{tabular}{lccccc}
\hline \multicolumn{1}{c|}{1} & 2 & 3 & 4 & 5 \\
\hline Carbonate calcium & 0.72 & 0.70 & 0.59 & 0.50 \\
Glyco-Line & 0.93 & 0.85 & 0.82 & 0.80 \\
Chemical composition: & & & & \\
$\quad \mathrm{DM}(\mathrm{g} / \mathrm{kg})$ & 51 & 51.7 & 49.5 & 49 \\
$\mathrm{NE}_{1}(\mathrm{Mcal} / \mathrm{kg})$ & 15.1 & 15.1 & 15.9 & 15.9 \\
$\mathrm{CP}(\mathrm{g} / \mathrm{kg})$ & 11.9 & 14.2 & 14.0 & 16.8 \\
$\mathrm{EE}(\mathrm{g} / \mathrm{kg})$ & 3.7 & 3.7 & 8.7 & 8.7 \\
$\mathrm{CF}(\mathrm{g} / \mathrm{kg})$ & 28.3 & 28.3 & 22.3 & 22.3 \\
$\mathrm{NDF}^{2}(\mathrm{~g} / \mathrm{kg})$ & 36 & 36.2 & 31.5 & 31.2 \\
$\mathrm{Ash}(\mathrm{g} / \mathrm{kg})$ & 12.2 & 12.6 & 12.4 & 12 \\
\hline
\end{tabular}

*Prepartum refers to the period of 21 days prior to calving; Postpartum refers to the period of 21 days postcalving.

${ }^{1}$ Contained 196 g Ca, 96 g P, 71 g Na, 19 g Mg, 3 g Fe, 0.3 g Cu, 2 g Mn, 3 g Zn, 100 ppm Co, 100 ppm I, $0.1 \mathrm{ppm}$ Se and $50 \times 105 \mathrm{IU}$ of vitamin A, $10 \times 105 \mathrm{IU}$ of vitamin D and $0.1 \mathrm{~g}$ of vitamin $\mathrm{E} / \mathrm{kg}$.

${ }^{2} \mathrm{NDF}$, neutral detergent fiber.

Table 2. Gender of calves and number of calves distributed between treatments

\begin{tabular}{l|c|c}
\hline & Moderate CP & High CP \\
\hline Male calves & 6 & 7 \\
Female calves & 9 & 8 \\
\hline
\end{tabular}

\section{Diet analysis}

The prepartum and postpartum diets were sampled weekly, dried at $60^{\circ} \mathrm{C}$ for $48 \mathrm{~h}$, ground initially through a Wiley mill (2-mm screen; Arthur H. Thomas, Philadelphia, PA), then in a cyclone mill (1-mm screen; Udy Co., Fort Collins, CO) and subsequently analyzed for dry matter, $\mathrm{CP}$ and ether extract (EE) according to AOAC (1990). Neutral detergent fiber (NDF) (Van Soest et al., 1991) and ash (incineration at $550^{\circ} \mathrm{C}$ for $24 \mathrm{~h}$ ) also were analyzed.

\section{Lactation performance and milk content}

Cows were milked 3 times a day at 8:30, 14:30 and 20:30 h. Milk yield was recorded 3 times during each of day 15 and 30 postpartum. Furthermore, milk samples also were collected at the same time and transferred to laboratory for fat, protein, lactose and solids not fat (SNF) analysis by Lactostar (Funke-Dr.N. Gerber Labortechnik $\mathrm{GmbH}$ ). Mean values of the recorded milk yield and milk composition in those two days were used for subsequent analysis.

\section{Chemical composition and immunological properties of colostrum}

Colostrum samples of cows were collected during the first milking. Each sample was labeled with the identity of the cow/calf pair, and then frozen at $-80^{\circ} \mathrm{C}$ for subsequent analysis. Colostrum samples were thawed at room temperature and thoroughly mixed and then analyzed for fat, protein, lactose, and SNF by infrared spectrophotometer (System 4000 MilkoScan; Foss Electric, Hillerød, Denmark).

Immunoglobulin and total globulins concentration of colostrum samples was separated by Rivanol procedure (Kenyon et al., 1959). In this regard, 3.5 volume of 
$0.4 \%$ aqueous rivanol solution was added to one volume of colostrum, then the $\mathrm{pH}$ adjusted to 8.5 and centrifuged to obtain the precipitated IgG. Afterwards, rivanol was removed from the supernatant by adsorption on activated charcoal and IgG was determined by radial immunodiffusion technique (Triple J Farms, Redmond, WA).

Serum total globulins and IgG concentration of dairy cows and their calves

Blood samples of cows were taken from the coccygeal vein at 4 hours after feeding on day 21, two days before projected calving date and also 15 and 30 days after parturition. Besides that, blood samples of all calves were collected from the jugular vein at $72 \mathrm{~h}$ and also on days 7, 14, 21 and 28 postcalving. Samples were centrifuged at $3000 \times \mathrm{g}$ (Hettich; D-78532 Tuttlingen, Germany) for 10 minutes in order to separate serum and then serum was frozen at $-20^{\circ} \mathrm{C}$ for later analysis. IgG and total globulins concentration of serum samples were separated by Rivanol procedure (Kenyon et al., 1959) and measured by turbidimetric immunoassay (Etzel et al., 1997).

\section{Statistical analysis}

Data were analyzed as a complete randomized block design using the general linear model procedure of SAS (SAS Institute, 2000). The differences between the means were ascertained by Tukey post-hoc test and significance was declared at $\mathrm{P}<0.05$. The experimental models were as follows:

$$
Y_{i j k}=\mu+T_{i}+B_{k}+E_{i j k}
$$

where:

$\mu$ - overall mean,

$T_{i}$ - high protein diet,

$B_{k}$ - parity,

$E_{i j k}-$ residual error.

$$
Y_{i j k}-\mu+T_{i}+E_{i j k}
$$

where:

$\mu$ - overall mean,

$T_{i}-$ colostrum,

$E_{i j k}-$ residual error.

Pearson test was used to analyze the relationship between values of the present study.

\section{Results}

\section{Lactation performance and milk contents}

Average milk production was not significant between treatments, both at day 15 and 30 postpartum (Tables 3 and 4). On the other hand, applied treatments had no 
effect on milk composition. Similarly no significant effect of treatments for $4 \%$ fat corrected milk yield was shown.

Table 3. Milk production and composition of dairy cows on day 15

\begin{tabular}{l|c|c|c|c}
\hline \multirow{2}{*}{ Item } & \multicolumn{2}{c|}{ Treatments } & \multicolumn{2}{c}{ Significance } \\
\cline { 2 - 5 } & Moderate CP & High CP & SEM & P-value \\
\hline Milk yield (kg/day) & 35.6 & 36.2 & 1.82 & 0.718 \\
4\% FCM (kg/day) & 38.3 & 39.7 & 2.87 & 0.575 \\
Milk fat yield (kg/day) & 1.6 & 1.7 & 0.13 & 0.555 \\
Milk protein yield (kg/day) & 1.2 & 1.2 & 0.06 & 0.680 \\
Milk lactose yield (kg/day) & 1.7 & 1.7 & 0.08 & 0.789 \\
SNF yield (kg/day) & 3.8 & 3.9 & 0.18 & 0.575 \\
Milk fat (\%) & 4.3 & 4.6 & 0.24 & 0.420 \\
Milk protein (\%) & 3.4 & 3.4 & 0.05 & 0.764 \\
Milk lactose (\%) & 4.8 & 4.8 & 0.07 & 0.981 \\
SNF (\%) & 10.7 & 10.8 & 0.22 & 0.662 \\
\hline
\end{tabular}

Table 4. Milk production and composition of dairy cows on day 30

\begin{tabular}{l|c|c|c|c}
\hline \multirow{2}{*}{\multicolumn{1}{c}{ Item }} & \multicolumn{2}{c|}{ Treatments } & \multicolumn{2}{c}{ Significance } \\
\cline { 2 - 5 } & Moderate CP & High CP & SEM & P-value \\
\hline Milk yield (kg/day) & 41 & 40.7 & 1.87 & 0.970 \\
4\% FCM (kg/day) & 45.4 & 42.2 & 3.23 & 0.634 \\
Milk fat yield (kg/day) & 1.9 & 2.1 & 0.18 & 0.560 \\
Milk protein yield (kg/day) & 1.4 & 1.4 & 0.07 & 0.984 \\
Milk lactose yield (kg/day) & 1.9 & 2 & 0.09 & 0.907 \\
SNF yield (kg/day) & 4.3 & 4.2 & 0.20 & 0.753 \\
Milk fat (\%) & 4.7 & 5 & 0.33 & 0.497 \\
Milk protein (\%) & 3.4 & 3.4 & 0.05 & 0.922 \\
Milk lactose (\%) & 4.7 & 4.7 & 0.07 & 0.856 \\
SNF (\%) & 10.5 & 10.4 & 0.19 & 0.531 \\
\hline
\end{tabular}

\section{Chemical composition and immunological properties of colostrum}

Colostrum density of cows fed the diet with higher CP content was $0.38 \%$ lower than in the moderate group $(\mathrm{P}<0.05)$, whereas the other colostral components were not affected through feeding higher protein diet (Table 5).

Table 5. Effect of protein supplement on colostrum composition of experimental cows

\begin{tabular}{l|c|c|c|c}
\hline \multirow{2}{*}{ Item } & \multicolumn{2}{c|}{ Treatments } & \multicolumn{2}{c}{ Significance } \\
\cline { 2 - 5 } & Moderate CP & High CP & SEM & P-value \\
\hline Fat (\%) & 7.7 & 8.0 & 0.34 & 0.358 \\
Protein (\%) & 12.1 & 13.3 & 0.64 & 0.156 \\
Lactose (\%) & 2.8 & 3.0 & 0.08 & 0.210 \\
Density $\left(\mathrm{g} / \mathrm{cm}^{3}\right)$ & $1.060 \mathrm{a}$ & $1.056 \mathrm{~b}$ & 0.001 & 0.013 \\
IgG $(\mathrm{g} / \mathrm{l})$ & 69.0 & 68.2 & 7.61 & 0.924 \\
\hline
\end{tabular}

$\mathrm{a}, \mathrm{b}$ - values in the same row not sharing a common superscript differ significantly $(\mathrm{P}<0.05)$. 


\section{Serum total globulins and IgG concentration of dairy cows and their new- born calves}

Serum concentration of globulin and IgG of cows fed the higher CP diet tended to be greater than for cows fed moderate CP level in transition diet during pre- and postpartum periods. Moreover, cows fed the high-protein diet had $17.5 \%$ and $57.94 \%$ higher serum concentration of globulin and $\mathrm{IgG}$, respectively, on day 21 precalving compared to samples taken 2 days before parturition (Table 6).

Table 6. Effect of protein supplement on serum globulin and IgG concentrations of experimental cows

\begin{tabular}{l|c|c|c|c}
\hline & \multicolumn{2}{|c|}{ Treatments } & \multicolumn{2}{c}{ Significance } \\
\cline { 2 - 5 } & Moderate CP & High CP & SEM & P-value \\
\hline 21 d before calving & & & & \\
Globulin (mg/mL) & 47.7 & 49.0 & 1.91 & 0.780 \\
IgG (g/l) & 9.4 & 12.0 & 1.54 & 0.219 \\
2 d before calving & & & & \\
Globulin (mg/mL) & 39.3 & 40.50 & 1.86 & 0.839 \\
IgG (g/l) & 3.1 & 5.9 & 1.57 & 0.276 \\
15 d after calving & & & & \\
Globulin (mg/mL) & 42.5 & 42.9 & 2.29 & 0.971 \\
IgG (g/l) & 10.8 & 13.8 & 1.46 & 0.089 \\
30 d after calving & & & & \\
Globulin (mg/mL) & 45.8 & 46.4 & 2.52 & 0.814 \\
IgG (g/l) & 10.3 & 12.5 & 1.65 & 0.367 \\
\hline
\end{tabular}

Table 7. Effect of protein supplement on serum globulin and IgG concentrations of experimental calves

\begin{tabular}{|c|c|c|c|c|}
\hline & \multicolumn{2}{|c|}{ Treatments } & \multicolumn{2}{|c|}{ Significance } \\
\hline & Moderate CP & High CP & SEM & P-value \\
\hline \multicolumn{5}{|l|}{$72 \mathrm{~h}$ after birth } \\
\hline Globulin $(\mathrm{mg} / \mathrm{mL})$ & 23.6 & 26.1 & 2.04 & 0.389 \\
\hline $\operatorname{IgG}(\mathrm{g} / \mathrm{l})$ & 7.8 & 10.8 & 1.44 & 0.065 \\
\hline \multicolumn{5}{|l|}{$7 \mathrm{~d}$ after birth } \\
\hline Globulin $(\mathrm{mg} / \mathrm{mL})$ & 23.3 & 26.6 & 2.31 & 0.332 \\
\hline $\operatorname{IgG}(\mathrm{g} / \mathrm{l})$ & 7.0 & 6.7 & 1.57 & 0.827 \\
\hline \multicolumn{5}{|l|}{$14 \mathrm{~d}$ after birth } \\
\hline Globulin $(\mathrm{mg} / \mathrm{mL})$ & 27.7 & 31.0 & 1.6 & 0.155 \\
\hline $\operatorname{IgG}(\mathrm{g} / \mathrm{l})$ & 6.5 & 5.3 & 0.88 & 0.323 \\
\hline \multicolumn{5}{|l|}{$21 \mathrm{~d}$ after birth } \\
\hline Globulin $(\mathrm{mg} / \mathrm{mL})$ & 28.7 & 31.9 & 2.16 & 0.296 \\
\hline $\operatorname{IgG}(\mathrm{g} / \mathrm{l})$ & $3.7 \mathrm{~b}$ & $6.0 \mathrm{a}$ & 0.78 & 0.048 \\
\hline \multicolumn{5}{|l|}{$28 \mathrm{~d}$ after birth } \\
\hline Globulin $(\mathrm{mg} / \mathrm{mL})$ & 25.4 & 27.4 & 1.58 & 0.387 \\
\hline $\operatorname{IgG}(\mathrm{g} / \mathrm{l})$ & 4.5 & 4.6 & 0.82 & 0.931 \\
\hline
\end{tabular}

$\mathrm{a}, \mathrm{b}$ - values in the same row not sharing a common superscript differ significantly $(\mathrm{P}<0.05)$. 
Table 8 . The correlations between chemical and physical colostral composition of experimental cows

\begin{tabular}{l|c|c|c|c|c}
\hline \multicolumn{1}{c}{ Composition } & $\begin{array}{c}\mathrm{IgG} \\
(\mathrm{g} / \mathrm{l})\end{array}$ & $\begin{array}{c}\mathrm{SNF} \\
(\%)\end{array}$ & $\begin{array}{c}\text { Density } \\
\left(\mathrm{g} / \mathrm{cm}^{3}\right)\end{array}$ & $\begin{array}{c}\text { Lactose } \\
(\%)\end{array}$ & $\begin{array}{c}\text { Protein } \\
(\%)\end{array}$ \\
\hline $\mathrm{IgG}(\mathrm{g} / \mathrm{l})$ & 11.000 & 0.083 & 0.063 & -0.728 & 0.782 \\
& 20.000 & 0.665 & 0.740 & $<0.001$ & $<0.001$ \\
$\mathrm{SNF}(\%)$ & & & & & \\
& & 1.000 & 0.983 & -0.003 & -0.016 \\
& & 0.000 & 4.140 & 0.988 & 0.933 \\
Density $\left(\mathrm{g} / \mathrm{cm}^{3}\right)$ & & & 1.000 & -0.004 & -0.015 \\
& & & 0.000 & 0.983 & 0.938 \\
Lactose (\%) & & & & 1.000 & -0.999 \\
& & & & 0.000 & 3.000 \\
Protein $(\%)$ & & & & 1.000 \\
& & & & & 0.000 \\
\hline
\end{tabular}

${ }^{1}$ Correlation.

${ }^{2}$ Significance.

Compared with the group fed moderate CP level transition diet, calves from the group fed higher CP diet had 27.8\% greater mean serum IgG concentration at $72 \mathrm{~h}$ after birth and significantly improved at 21 days of age $(\mathrm{P}<0.05)$ (Table 7$)$. All calves in the higher $\mathrm{CP}$ group marginally exhibited increased total globulins concentration.

\section{Correlations}

The correlation between chemical and physical colostral composition of experimental cows is presented in Table 8. A significant negative correlation was shown between colostral lactose and $\operatorname{IgG}$ concentration $(\mathrm{r}=-0.728 ; \mathrm{P}<0.001)$. Furthermore, colostral protein and IgG concentration were significantly and positively correlated $(\mathrm{r}=0.728 ; \mathrm{P}<0.001)$. The IgG concentration in serum samples of cows 2 days before projected calving date and its concentration in serum samples of calves at $72 \mathrm{~h}$ after birth was not correlated $(\mathrm{r}=0.159 ; \mathrm{P}=0.469)$. On the other hand, a tendency for negative correlation was observed between serum IgG of cows and their colostral IgG concentration $(\mathrm{r}=-0.376 ; \mathrm{P}=0.064)$. Inversely, a positive and significant correlation has been obtained between colostral $\mathrm{IgG}$ and serum $\mathrm{IgG}$ concentration of calves $(\mathrm{r}=0.543 ; \mathrm{P}=0.003)$.

\section{Discussion}

Milk production of cows on days 15 and 30 postpartum was not affected by increasing protein level of transition diet. Most of researchers have reported the increase of milk yield using protein supplement in prepartum period (Van Saun et al., 1993; Moorby et al., 1996) but increasing protein level in transition phase is less investigated. Putnam et al. (1999) fed cows with 3 different levels of CP (10.6, 12.7 and $14.5 \%$ ) before calving and observed no marked difference in subsequent 
milk production postpartum. Huyler et al. (1999) also reported that increasing dietary protein in prepartum using a source of rumen undegradable protein did not enhance milk production after calving. In contrast, Santos et al. (2001) indicated the increased milk production over the 120 milking days postpartum via feeding of high protein diet before parturition. Supplementing protein in late gestation has been reported to make no significant changes in milk composition (Huyler et al., 1999). For the same trend, the results of the current research also failed to show any effect of increasing protein level across transition period on milk composition. In contrast, some studies suggested that using protein supplement only before calving increased milk protein content (Van Saun et al., 1993; Moorby et al., 1996).

In this experiment, the higher CP fed group had lower colostral density than the group fed moderate CP content, which is similar to the findings of Kehoe et al. (2007) and Zarcula et al. (2010). Moreover, in the current data as well as other studies (Hough et al., 1990; Santos et al., 2001) no effect of increased dietary protein before calving on colostral IgG was shown, but Stockdale and Smith (2004) suggested that nutrition in dry period affected colostral IgG concentration at the first milking. One probable reason for these contradictory results may relate to the volume of the colostrum. Accordingly, previous reports have shown a negative correlation between volume of first milking and colostral $\mathrm{IgG}_{1}$ which might be in part due to dilution by accumulated milk rather than inadequate $\mathrm{IgG}_{1}$ transport activity (Guy et al., 1994). Similarly, Pritchett et al. (1991) found a negative correlation between volume and concentration of $\operatorname{IgG}_{1}$ in colostrum. Therefore, in this study decreased colostrum density and lack of the significant change in IgG concentration might result from the alteration in volume of the colostrum.

The slight increase of serum total globulins and $\mathrm{IgG}$ in cows fed higher level of $\mathrm{CP}$ compared with cows in moderate CP group during pre- and postpartum periods could be related to the impact of increased protein level in transition diet on serum immunoglobulin of the cows. Unlike the current trial, there are reports pointing out that dietary protein level had no major effect on serum total globulins concentration (Hamed et al., 2001; Law et al., 2009). The serum concentration of total globulins and $\mathrm{IgG}$ on day 21 precalving reduced approaching calving time in animals fed higher CP diet. This reduction may be associated with decreased lymphocytes ratio and their functional activities such as cloning expansion and antibody production in late pregnancy (Detilleux et al., 1995; Kimura et al., 1999). Another possible explanation is that reduction in serum IgG concentration close to parturition is induced by the translocation of immunoglobulin into the udder tissue (Herr et al., 2011).

Compared with the moderate CP group, calves fed increased CP diet had 27.8\% higher serum IgG concentration at $72 \mathrm{~h}$ after the birth, although this difference was not statistically significant. According to the results of Kruse et al. (1970), more than $50 \%$ of dispersion in serum antibody concentration of calves depends on the amount of antibodies absorbed from colostrum. A positive correlation also has been observed between the consumed values of antibody and its absorption in neonatal calves (McEwan et al., 1970). Additionally, Weaver et al. (2000) concluded that the most important factors influencing the absorption of immunoglobulin and serum IgG concentration in neonatal calves are the consumed IgG mass and volume of the co- 
lostrum. Based on the current data, it seems that increased prepartum protein intake affected the serum IgG concentration of calves. On the other hand, serum IgG concentration significantly increased at 21 days of age in those calves fed colostrum of dams that were offered higher CP level during transition period. Logan et al. (1974) reported that endogenous production of $\mathrm{IgG}$ in calves receiving higher $\mathrm{IgG}$ started at the age of 4 weeks. Therefore, higher IgG concentration of calf's serum in higher CP group at the third week after parturition might be attributed to the stimulant role of increased protein intake by the mother before calving and its effect on endogenous production in their body.

The significant correlation found between colostral protein and IgG concentration in this study is in agreement with the results of Quigley et al. (2002). The IgG concentration in serum samples of cows 2 days before expected calving date and its concentration in serum samples of calves at $72 \mathrm{~h}$ after birth did not show high correlation. On the other hand, a negative correlation between serum IgG of cows and their colostral IgG concentration was observed. These results express the lack of direct relationship between serum IgG concentration of cows before calving and serum IgG of their calves $72 \mathrm{~h}$ after expected calving date. This also indicates a close correlation between serum $\mathrm{IgG}$ in dams and appearance of $\mathrm{IgG}$ in their colostrum. Therefore, it is likely that IgG concentration in cow's serum was transferred to reach optimal level of IgG content in colostrum before calving which confirms the beliefs about passive transfer of immunity from dam to the calf.

\section{Conclusions}

In conclusion, using high protein diet in transition period did not influence milk yield recorded on days 15 and 30 after parturition. Although increasing prepartum dietary CP decreased colostral density, no significant effect on chemical composition or immunological content in colostrum was shown. The serum IgG concentration of dairy cows partially decreased before calving time and gradually increased after parturition. Serum IgG of calves was significantly elevated 3 weeks after parturition. A negative correlation was found between serum IgG of cows prepartum and colostral IgG. Moreover, colostral IgG and serum IgG of calves were significantly correlated, which confirmed the relationship of colostrum and IgG concentration in the serum of neonatal calves. Therefore, the increased protein level during periparturient period tended to improve immune status of calves.

\section{References}

AOAC (1990). Official methods of analysis of the Association of Official Analytical Chemists. 15th ed., AOAC International, Gaithersburg, Maryland, USA.

B a $\mathrm{n}$ k s K.L. (1982). Host defense in the newborn animal. J. Am. Vet. Med. Assoc., 181: 1053-1056.

B arrington G.M., M c F a d d en T.B., Hu y ler M.T., B e s s e r T.E. (2001). Regulation of colostrogenesis in cattle. Livest. Prod. Sci., 70: 95-104.

B 1 u m J.W. (2006). Nutritional physiology of neonatal calves. J. Anim. Physiol. Anim. Nutr., 90: $1-11$.

B urton J.L., Ers k in e R.J. (2003). Immunity and mastitis. Some new ideas for an old disease. Vet. Clin. North. Am. Food. Anim. Pract., 19: 1-45. 
Detilleux J.C., Kehrli Jr M.E., Stabel J.R., Freeman A.E., Kelley DH. (1995). Study of immunological dysfunction in periparturient Holstein cattle selected for high and average milk production. Vet. Immunol. Immunopathol., 44: 251-267.

Etzel L.R., Strohbehn R.E., Mc Vicker J.K. (1997). Development of an automated turbidimetric immunoassay for quantification of bovine serum immunoglobulin G. Am. J. Vet. Res., 58: 1201-1205.

G o d d e n S. (2008). Colostrum management for dairy calves. Vet. Clin. North. Am. Food. Anim. Pract., 24: 19-39.

G u o J., P e t e r s R.R., K o h n R.A. (2007). Effect of a transition diet on production performance and metabolism in periparturient dairy cows. J. Dairy Sci., 90: 5247-5258.

Gu y M.A., M c F a d d en T.B., C o c kre 11 D.C., B e s s e r T.E. (1994). Effects of unilateral prepartum milking on concentrations of immunoglobulin G1 and prolactin in colostrum. J. Dairy Sci., 77: 3584-3591.

H a med D., F averdin P., Verité R. (2001). Effects of the level and source of dietary protein on intake and milk yield in dairy cows. Anim. Res., 50: 205-211.

He r r M., B o s t e d t H., F a i 1 in g K. (2011). IgG and IgM levels in dairy cows during the periparturient period. Theriogenology, 75: 377-385.

Hough R.L., M c Carthy F.D., Kent H.D., Ever s o le D.E., Wa hlberg M.L. (1990). Influence of nutritional restriction during late gestation on production measures and passive immunity in beef cattle. J. Anim. Sci., 68: 2622-2627.

H u y le r M.T., K i n c a i d R. L., D o s t a 1 D. F. (1999). Metabolic and yield responses of multiparous Holstein cows to prepartum rumen-undegradable protein. J. Dairy Sci., 82: 527-536.

J a s t e r E.H. (2005). Evaluation of quality, quantity, and timing of colostrum feeding on immunoglobulin $G_{1}$ absorption in Jersey calves. J. Dairy Sci., 88: 296-302.

K e ho e S.I., J a y a r a B.M., H e in ri ch s A.J. (2007). A survey of bovine colostrum composition and colostrum management practices on Pennsylvania dairy farms. J. Dairy Sci., 90: 4108-4116.

Kenyon A.J., Anders on R.K., Jenness R. (1959). Isolation of immune globulins from milk and colostrum with rivanol. J. Dairy Sci., 42: 1233-1234.

K i m u r a K., G o ff J.P., K e hr l i Jr M.E., H a r p J.A. (1999). Phenotype analysis of peripheral blood mononuclear cells in periparturient dairy cows. J. Dairy Sci., 82: 315-319.

Kru s e V. (1970). Absorption of immunoglobulin from colostrum in newborn calves. Anim. Prod., 12: $627-638$.

Law R.A., Young F.J., Patterson D.C., Kilpatrick D.J., Wylie A.R.G., Mayne C.S. (2009). Effect of dietary protein content on animal production and blood metabolites of dairy cows during lactation. J. Dairy Sci., 92: 1001-1012.

Logan E.F., Sten hous e A., P enhale W.J., Armis haw M., Ormrod D. (1974). Studies on the immunity of the calf to colibacillosis VI: the prophylactic use of a pooled serum IgM-rich fraction under field conditions. Vet. Rec., 94: 386-389.

M c Ew a n A.D., F is h e r E.W., S e $1 \mathrm{~m}$ a n I.E. (1970). Observations on the immune globulin levels of neonatal calves and their relationship to disease. J. Com. Pathol., 11: 239-243.

M o orby J.M., D e wh urs R.J., M ars den S. (1996). Effect of increasing digestible undegraded protein supply to dairy cows in late gestation on the yield and composition of milk during the subsequent lactation. Anim. Sci., 63: 201-213.

Pritchett L.C., G a y C.C., B es s er T.E., H a n c o ck D.D. (1991). Management and production factors influencing immunoglobulin G1 concentration in colostrum from Holstein cows. J. Dairy Sci., 74: 2336-2341.

Putnam D.E., Varga G.A., D ann H.M. (1999). Metabolic and production responses to dietary protein and exogenous somatotropin in late gestation dairy cows. J. Dairy Sci., 82: 982-995.

Quigley J.D., Kost C.J., Wolfe T.M. (2002). Absorption of protein and IgG in calves fed a colostrum supplement or replacer. J. Dairy Sci., 85: 1243-1248.

S a n to s J.E.P., D e P et e r s E.J., J a rd on P.W., Hub er J.T. (2001). Effect of prepartum dietary protein level on performance of primigravid and multiparous Holstein dairy cows. J. Dairy Sci., 84: 213-224.

S t o c kd a l e C.R., S m i th C.J. (2004). Effect of energy and protein nutrition in late gestation on immunoglobulin $\mathrm{G}$ in the colostrum of dairy cows with varying body condition scores. Anim. Prod. Aust., 1: 176-179. 
U r u a k p a F.O., I s m on d M.A.H., A k o b und u E.N.T. (2002). Colostrum and its benefits: a review. Nutr. Res., 22: 755-767.

Van S a un R.J., I d l e m a n S.C., S n iffe n C.J. (1993). Effect of undegradable protein amount fed prepartum on postpartum production in first lactation Holstein cows. J. Dairy Sci., 76: 236-244.

Van S oest P.J., R ob e r t s o n J.B., L e w is B.A. (1991). Methods for dietary fiber, NDF and nonstarch polysaccharides in relation to animal nutrition. J. Dairy Sci., 74: 3568-3597.

Weaver D.M., Tyler J.W., Van Metre D.C., Hos tetler D.E., B arrington G.M. (2000). Passive transfer of colostral immunoglobulins in calves. J. Vet. Intern. Med., 14: 569-577.

Zarcula S., Cernescu H., Mircu C., Tulcan C., Morvay A., Baul S., Popovici D. (2010). Influence of breed, parity and food intake on chemical composition of first colostrum in cow. Anim. Sci. Biotechnol., 43: 154-157.

Received: 31 III 2014

Accepted: 3 XI 2014 